\title{
Report of brachyuran crabs (Crustacea, Decapoda) from the Pliocene of Borgomanero, Novara (Piedmont, NW Italy)
}

\author{
Giovanni Pasini ${ }^{1}$, Alessandro Garassino ${ }^{2 *}$, Piero Damarco ${ }^{3}$
}

\begin{abstract}
Some brachyuran crabs from the Pliocene of a new outcrop nearby Borgomanero (Novara, Piedmont, NW Italy) are reported. This study allows us to recognize a peculiar brachyuran crabs assemblage including: Macropipus cf. M. tuberculatus Prestandrea, 1833 (Polybiidae Ortmann, 1893), first report for this species from the Pliocene fossil record, and an indeterminate representative of Mursia Leach in Desmarest, 1822 (Calappidae De Haan, 1833), genus never recorded previously in the Mediterranean basin. Finally, a single chela is referred to Calappa sp. (Calappidae De Haan, 1833).
\end{abstract} Italy.

Key words: Decapoda, Brachyura, Pliocene, Piedmont, NW

Riassunto - Nuovi crostacei brachiuri (Crustacea, Decapoda) del Pliocene di Borgomanero, Novara (Piemonte, NO Italia).

Viene segnalata la presenza di alcuni nuovi brachiuri (Crustacea, Decapoda), da una nuova località del Pliocene presso Borgomanero (Novara, Piemonte, Italia nord-occidentale). Lo studio ha permesso di riconoscere una particolare associazione di crostacei brachiuri che include Macropipus cf. M. tuberculatus Prestandrea, 1833 (Polybiidae Ortmann, 1893), prima segnalazione del genere nel record fossile del Pliocene, e di un indeterminato rappresentante di Mursia Leach in Desmarest, 1822 (Calappidae De Haan, 1833), genere mai segalato prima nel bacino del Mediterraneo. Infine una singola chela è stata attribuita a Calappa sp. (Calappidae De Haan, 1833).

Parole chiave: Decapoda, Brachyura, Pliocene, Piemonte, Italia nordoccidentale.

\footnotetext{
${ }^{1}$ Via Alessandro Volta 16, 22070 Appiano Gentile (CO), Italia. E-mail: juanaldopasini@tiscali.it

${ }^{2}$ Sezione di Paleontologia degli Invertebrati, Museo di Storia Naturale, Corso Venezia 55, 20121 Milano, Italia

${ }^{3}$ Ente Gestione Parco Paleontologico Astigiano - Museo Paleontologico Territoriale dell'Astigiano, Corso V. Alfieri 381, 14100 Asti (AT), Italia.

E-mail: piero.damarco@posta.parchiastigiani.org

* Corresponding author: alessandro.garassino@comune.milano.it; alegarassino@gmail.com
}

(C) 2018 Giovanni Pasini, Alessandro Garassino, Piero Damarco

Received: 16 November 2017

Accepted for publication: 22 December 2017

\section{INTRODUCTION}

The studied specimens were collected along a small natural excavation produced by a seasonal creek running along the side of the Piedmont Prealpi Mountains nearby Borgomanero (Novara, NW Italy) $\left(45^{\circ} 43^{\prime} 13^{\prime \prime} \mathrm{N}\right.$, $\left.8^{\circ} 16^{\prime} 28^{\prime \prime} \mathrm{E}\right)$. Here, a short lens of fossiliferous fine gray, sandy clays about three meters thick crops out from the covering woodland. Decapod remains are quite rare and usually fragmentary or too poorly preserved to allow a systematic assignment. The associated fauna includes mainly mollusks, some corals, and bryozoans. Among the peculiar mollusk faunal assemblage, not studied yet, the presence of the uncommon fossil and extant Patella caerulea Linnaeus, 1758 (Eogastropoda, Patellidae) is remarkable, preserving also traces of the original color (Fig. 1). The species is poorly reported in the Pliocene of Italy with two different forms, Patella caerulea stellata and $P$. caerulea subplana having antitropical distribution from mesolittoral to coastal environments, indicating the presence of hard substrates. They are more commonly reported in Italy from Pleistocene deposits (Forli pers. comm., 2015). Unfortunately it is not possible to know if the Patella specimens come from the same layer preserving the studied specimens, or if it was simply washed from the uppermost overlaying layers of the section. As for other deposits along the Northern Italy Prealpi Mountains, the original Pliocene deposits were strongly eroded by glacial activity and subsequently washed by the alluvial events during the Pleistocene. Therefore, usually only some small strips of the deposits at the lowermost limit of the circalittoral Pliocene paleo-Mediterranean Sea environment are preserved. The studied fossiliferous locality has never been previously reported in the paleontological record. Only Baretti \& Sacco (1885), Parona (1886, 1903), and Garassino et al. (2004) reported some Pliocene fossiliferous localities, cropping out around the Borgosesia area, Gozzano village, and near the south west coast of the Orta Lake, located some kilometers northern of the new locality along the northern border of the Pliocene paleo Adriatic Gulf.

The studied specimens are herein generically assigned to the Pliocene $s$. l., based on the geographic proximity and sedimentological affinities with correlated layers and paleontological evidences, supported by the molluscan associated fauna, including Cymatium doderleini (D’Ancona), Distorsio (Rhysema) tortuosa (Borson), Eo- 


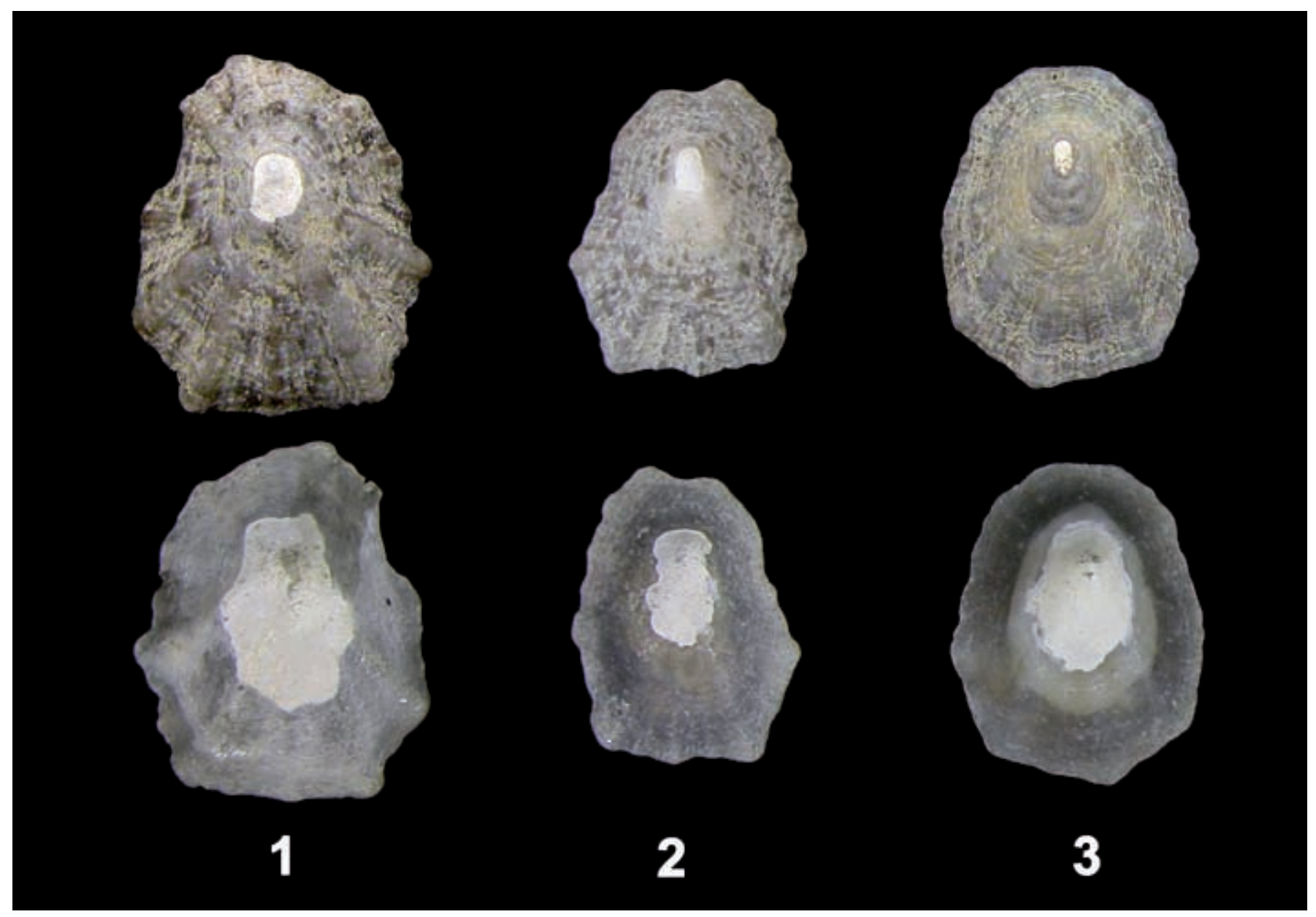

Fig. 1 - Patella caerulea Linnaeus, 1758; specimens from the Borgomanero outcrop in dorsal and ventral views (1 - H: $16.7 \mathrm{~mm}$; 2 H: $13.8 \mathrm{~mm} ; 3-\mathrm{H}: 15 \mathrm{~mm}$ ).

cypraea (Apiocypraea) parvoastensis (Sacco), Gyrineum (Aspa) marginatum (Martini), Hastula (H.) farinesi (Fontannes), Isognomon cf. I. maxillatus (Lamarck), and Venus exentrica (Agassiz), all species limited to the early Pliocene (Damarco pers. comm., 2017). The knowledge of the Pliocene decapod faunas from Piedmont was increased by different authors during these last years (for complete list see: Pasini \& Garassino, 2015a, b; Pasini et al., 2016). Therefore, this new report results to be a further important step in the general knowledge on the presence and distribution of the fossil decapod taxa in the western Padanian Gulf and in the Pliocene Mediterranean basin. The peculiar brachyuran assemblage of Borgomanero includes: Macropipus cf. M. tuberculatus (Roux, 1830) herein reported for the first time from the Pliocene fossil record, Mursia sp. herein reported for the first time in the Mediterranean basin. Finally one specimen is referred to Calappa sp.

Due to the delicate nature of the thin cuticle and incoherence of the sandy matrix, the specimens were fixed with a film of polyvinyl acetate solution for study and preservation. The specimens are housed in the paleontological collections of the Museo di Storia Naturale di Milano (MSNM) and Museo Paleontologico "Giulio Maini" di Ovada, Alessandria (MPOM).

\section{Abbreviations}

lcxp: carapace length; wcxp: carapace width.

\section{SYSTEMATIC PALAEONTOLOGY}

Section Eubrachyura de Saint Laurent, 1980

Subsection Heterotremata Guinot, 1977

Superfamily Calappoidea De Haan, 1883

Family Calappidae De Haan, 1833

\section{Genus Calappa Weber, 1795}

\section{Calappa sp. (Fig. 2)}

Material: One poorly preserved left chela in lateral view (MPOM 797).

Description: Subtriangular wide flat palm narrowing posteriorly with preserved fixed finger; stout wide and triangular fixed finger, upward-directed tip; occlusal margin with at least seven triangular, wide, and short teeth similar in size.

Discussion. Two characters of the chela, such the subtriangular shape, flattened and wide anteriorly and the short, stout, and triangular fixed finger, with upward- 


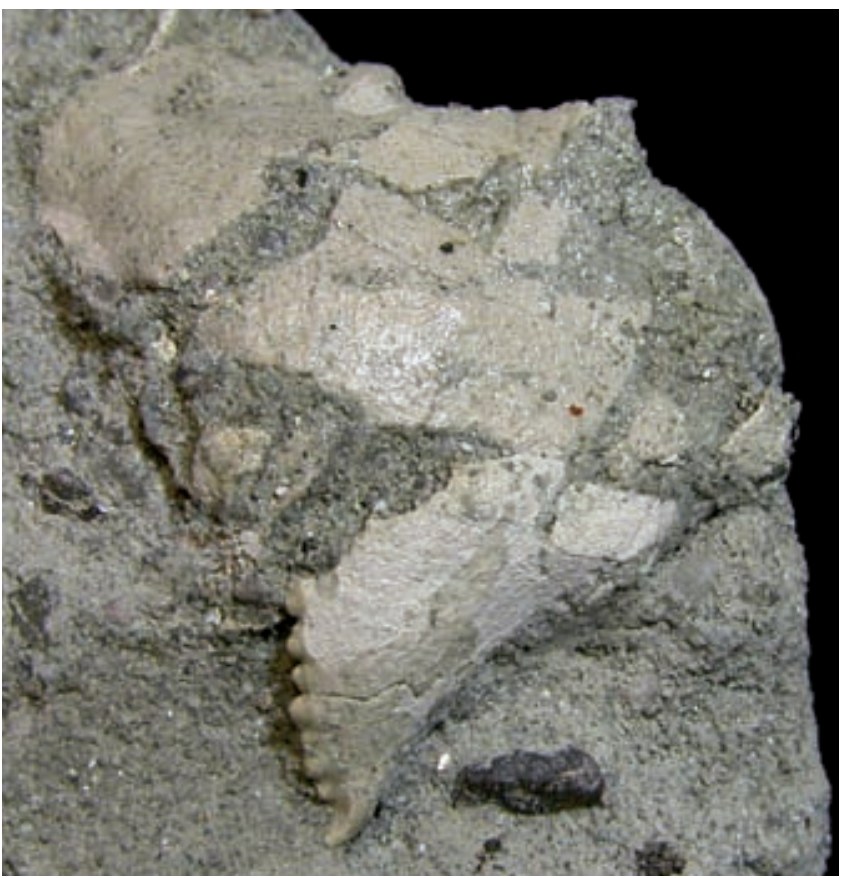

Fig. 2 - Calappa sp., MPOM 797 (x 6).

directed tip and occlusal triangular teeth margin allow us to ascribe the studied specimen to Calappa Weber, 1759 without specific assignment due to its incompleteness.

\section{Genus Mursia Leach in Desmarest, 1822}

\section{Mursia sp. (Fig. 3)}

Material and measurements: One carapace in dorsal view (MSNM i28549 - lcxp: $12 \mathrm{~mm}$; wcxp: $15 \mathrm{~mm}$ ).

Description: Carapace small, ovate distinctly vaulted transversely with five ridges of tubercles, wider than long, with maximum width in middle portion; convex anterolateral margins with several spaced tubercles or blunt teeth, arcuate anteriorly to the level of cardiac region; posterolateral margins strongly narrowed posteriorly, with straight narrow posterior margin; narrow frontal margin protruding anteriorly, poorly preserved; rounded small orbits forward directed; main dorsal regions marked by grooves; gastric regions defined by deep grooves, separated axially from branchial regions; grooves with some sparsely unequal tubercles; branchial regions with two additional shallow longitudinal grooves in each branchial region, the most lateral ones less deep; rounded tuberculate subparallel longitudinal ridges presents among the grooves; medial ridge stronger, bearing four-five large well-developed single tubercles arranged longitudinally and two pairs of transverse paired tubercles on the frontal region; similar arrangement of single less prominent tubercles decreasing posteriorly, present on the two shorter lateral branchial ridges.

Discussion. The studied specimen is herein referred to Mursia Leach in Desmarest, 1822 based upon the shape and ornamentation of the carapace, five dorsal ridges of

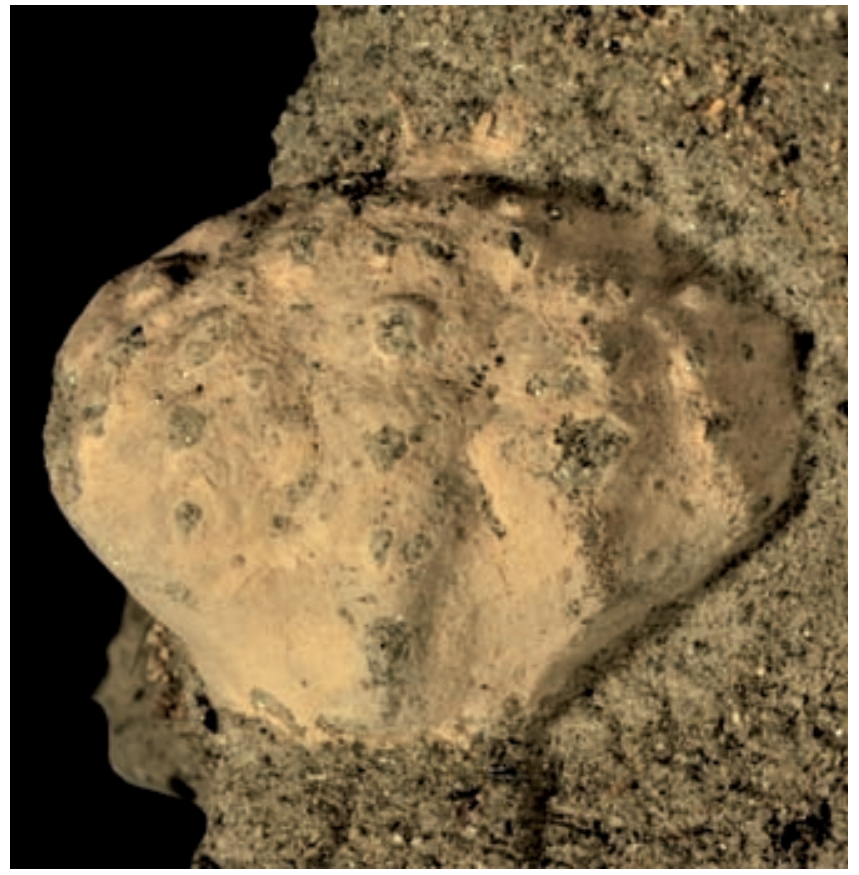

Fig. 3 - Mursia sp., MSNM i28549 (x 5).

tubercles, and narrow posterior margin. One peculiar difference with the majority of extant and fossil species of Mursia is the lack of one lateral spine (more or less developed) and reduced carapace ornamentation, though these characters are shared with M. aspina Schweitzer \& Feldmann, 2000 from the late Eocene of Washington, USA (Schweitzer \& Feldmann, 2000: 236, 237, Figs. 5.3-6, 7). However, it is not possible to verify on the studied specimen if the lateral spine is really absent, broken or simply worn due to the badly preservation.

The presence of Mursia is herein reported for the first time from the Pliocene Mediterranean basin.

Superfamily Portunoidea Rafinesque, 1815

Family Polybiidae Ortmann, 1893

Subfamily Polybiinae Ortmann, 1893

\section{Genus Macropipus Prestandrea, 1833}

\section{Macropipus cf. M. tuberculatus (Roux, 1830) (Fig. 4)}

Material and measurements: One incomplete carapace in dorsal view (MPOM 798).

Description: small suboval carapace, wider than long, whole dorsal surface coarsely granulate with tubercles often carinate; elevated dorsal regions defined by grooves; front with three distinct sharp teeth anteriorly directed, median tooth more projected than lateral ones; wide ovoid orbits, wide, about $1 / 2$ of the frontal margin; granulate dorsal orbital margins with a $\mathrm{V}$ sharped incision; anterolateral margin convex, with some spaced pointed teeth slightly curved anteriorly, poorly preserved (more than three, possibly 5?); posterolateral and posterior margin poorly preserved, probably straight. 


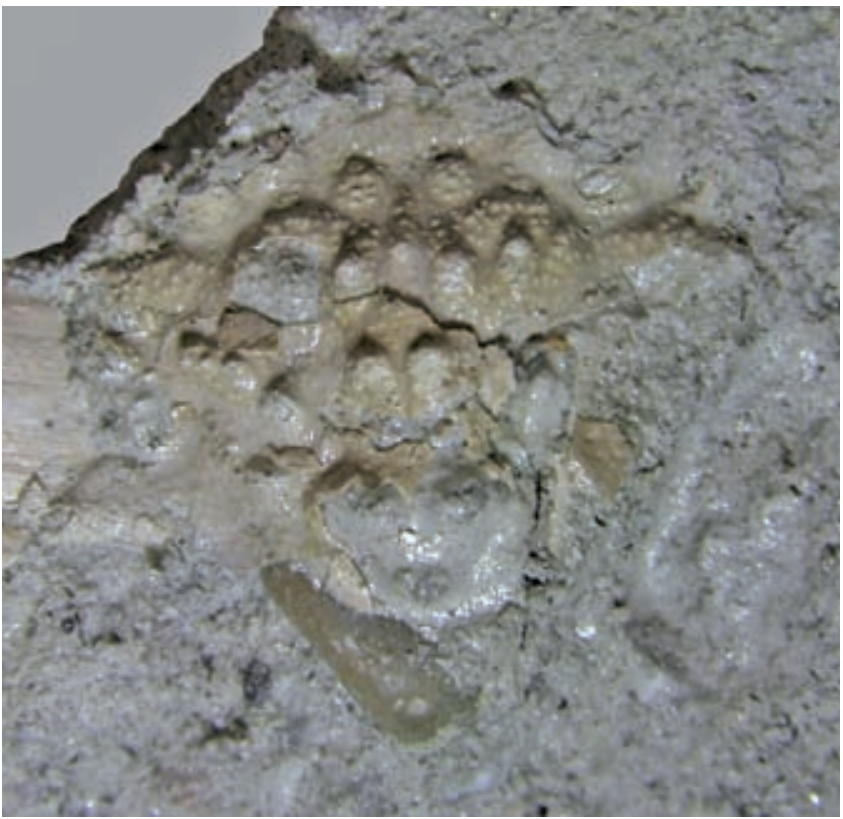

Fig. 4 - Macropipus cf. M. tuberculatus (Roux, 1830), MPOM 798 (x 6).

Discussion. Though the lateral and posterior margins are poorly preserved, the studied specimen shares some diagnostic characters distinctive with Macropipus tuberculatus (Roux, 1830), such as the "...dorsal carapace coarsely granulate with tubercles often carinate; elevated dorsal regions; front with three alternate teeth frontally directed with median tooth more projected than laterals ones; granulate dorsal orbital margins with a $V$ sharped incision and the anterolateral margin convex, with spaced pointed (5) teeth..." (Koch \& Duriš, 2016: 124). Due to the poor preservation, we prudentially compare the specimen with M. tuberculatus (Roux, 1830). This is the first record for this species in the fossil record, dating back to the Pliocene its presence in the Mediterranean Sea. Though Secrétan (1975) reported M. ovalipes from the middle Eocene of Monte Bolca (Verona, N Italy), the only representative for the genus known to date, its systematic assignment would need a critical review. The extant $M$. tuberculatus is distributed from the Eastern and N Atlantic to the Mediterranean Sea in sandy and clayey substrates, ranging from less than one meter (occasionally) to nearly 800 meters deep (Zariquiey Álvarez, 1968; d'Udekem d'Acoz, 1999).

\section{Acknowledgements}

We wish to thank L. Lacroce, Torino, who gave us the specimen of Mursia for study, E. Lavè, Borgomanero, Novara, for useful information on the Borgomanero outcrop; M. Forli, Società italiana di Malacologia (Prato) for useful suggestion on the mollusk associated fauna.

\section{REFERENCES}

Baretti M. \& Sacco F., 1885 - Il Mergozzolo. Club Alpino Italiano, Torino.
d'Udekem d'Acoz C., 1999 - Inventaire et distribution des crustacés décapodes de l'Atlantique nord-Oriental, de la Méditerranée et des eaux continentales adjacentes au nord de $25^{\circ} \mathrm{N}$. Muséum national d'Histoire naturelle, Paris, Patrimoines Naturels, 40.

Garassino A., De Angeli A., Gallo L.M. \& Pasini G., $2004-$ Brachyuran and anomuran fauna from the Cenozoico of Piedmont (NW Italy). Atti della Società italiana Scienze naturali e del Museo civico di Storia naturale in Milano, 145 (2): 251-281.

Koch M. \& Duriš Z., 2016 - Notes on distribution of some portunid crabs in Mediterranean Sea (Decapoda: Brachyura: Portunidae). Acta Musei Silesiae Scientiae Naturales, 65: 117-128. doi: 10.1515/cszma-20160015

Parona C.F., 1886 - Valsesia e Lago d'Orta. Tipografia Bernardoni di Rebeschini e C., Milano.

Parona C.F., 1903 - Trattato di Geologia. Biblioteca delle Scienze Fisiche e Naturali. Dott. F. Vallardi ediz., Milano.

Pasini G. \& Garassino A., 2015a - Petrochirrus fabroensis Pasini, Garassino \& De Angeli, 2014 (Anomura, Diogenidae) and Ranina sp. (Brachyura, Raninidae) from the Pliocene of Masserano (Piedmont, NW Italy). Natural History Sciences. Atti della Società italiana di Scienze naturali e del Museo civico di Storia naturale in Milano, 2 (1): 43-54.

Pasini G. \& Garassino A., 2015b - Petrochirus sanctilazzari Pasini, Garassino \& De Angeli., 2014 non Petrochirus fabroensis Pasini, Garassino \& De Angeli, 2014 (Anomura, Diogenidae) from the Pliocene of Masserano (Piedmont, NW Italy). Natural History Sciences. Atti della Società italiana di Scienze naturali e del Museo civico di Storia naturale in Milano, 2 (2): 149150. doi: $10.4081 /$ nhs.2015.258

Pasini G., Baldanza A., Gallo L.M., Garassino A. \& Karasawa H., 2016 - Anomuran and brachyuran trackways and resting trace from the Pliocene of Valduggia (Piedmont, NW Italy): environmental, behavioural, and taphonomic implications. Natural History Sciences. Atti della Società italiana di Scienze naturali e del Museo civico di Storia naturale in Milano, 3 (1): 35-48. doi: 10.4081/nhs.2016.281

Secrétan S., 1975 - Les crustacés du Monte Bolca. Studi e Ricerche sui Giacimenti Terziari di Bolca, 2: 315388.

Schweitzer C.E. \& Feldmann R.M., 2000 - New species of calappid crabs from western North America and reconsideration of the Calappidae sensu lato. Journal of Paleontology, 74 (2): 230-246.

Zariquiey Álvarez R., 1968 - Crustáceos Decápodos Ibéricos. Investigación Pesquera, 32: 1-499. 